\title{
The Housing Supply Puzzle: Part 2, Rental Demand
}

\author{
Evan Karson, Senior Research Associate \\ Joseph McGillicuddy, Senior Research Associate \\ B. Ravikumar, Senior Vice President and Deputy Director of Research
}

n Part 1 ("Divergent Markets") of this three-part series, we document that the recent divergence in inventories

of new and existing homes seems to reflect a scarcity of lower- and middle-tier homes. We now examine one potential factor contributing to this shortage: rental demand. Specifically, we investigate two channels through which this factor may have affected the supply of housing: increased conversion of single-family properties into rental units and a shift in new residential construction from single-family to multifamily units.

Several consecutive years of rental market strength appear to have contributed to the current housing shortage.

Over roughly the past decade, there has been a dramatic shift away from homeownership in favor of renting. According to the U.S. Census Bureau American Community Survey (ACS), in 2016 there were over 7 million additional renter-occupied housing units (including both single-family and multifamily structures) relative to 2006-an increase of 20 percent. Over the same 10-year period, the number of owner-occupied housing units remained unchanged and the national homeownership rate fell to 63 percent, the lowest annual level recorded by the U.S. Census Bureau since 1965. This movement toward renting is visible across all age groups. During the period, homeownership rates fell by 10 percentage points for young households, 6 percentage points for middle-aged households, and 2 percentage points for older households. ${ }^{1}$ As the shift occurred, rental rates climbed relative to home prices, as reflected by a 20 percent drop in the home price-to-rent ratio between 2006 and 2016.

One way the strengthening of rental demand has potentially decreased the supply of lower- and middle-tier homes is through an increase in renter occupancy of singlefamily properties. This trend may have reduced housing inventories because rental homes tend to be bought and sold less frequently than owner-occupied homes since landlords can hold on to properties as households move in and out. The ACS shows that renters accounted for nearly 19 percent of households living in single-family units in 2016, up from around 15 percent in 2006 (Figure 1). This reflects an increase of 3.8 million renter-occupied

Figure 1

Renter-Occupied Single-Family Homes as a Fraction of All Occupied Single-Family Homes

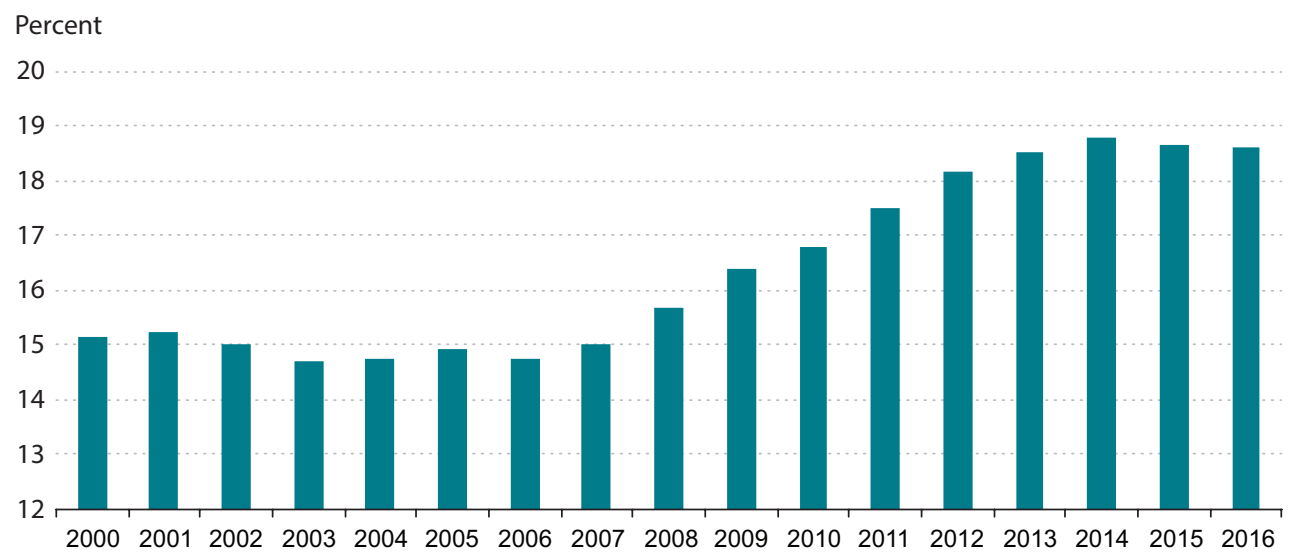

NOTE: Includes attached single-family homes.

SOURCE: ACS and authors' calculations. 


\section{Figure 2 \\ Fraction of Residential Starts That Are Single-Family Homes, SA}

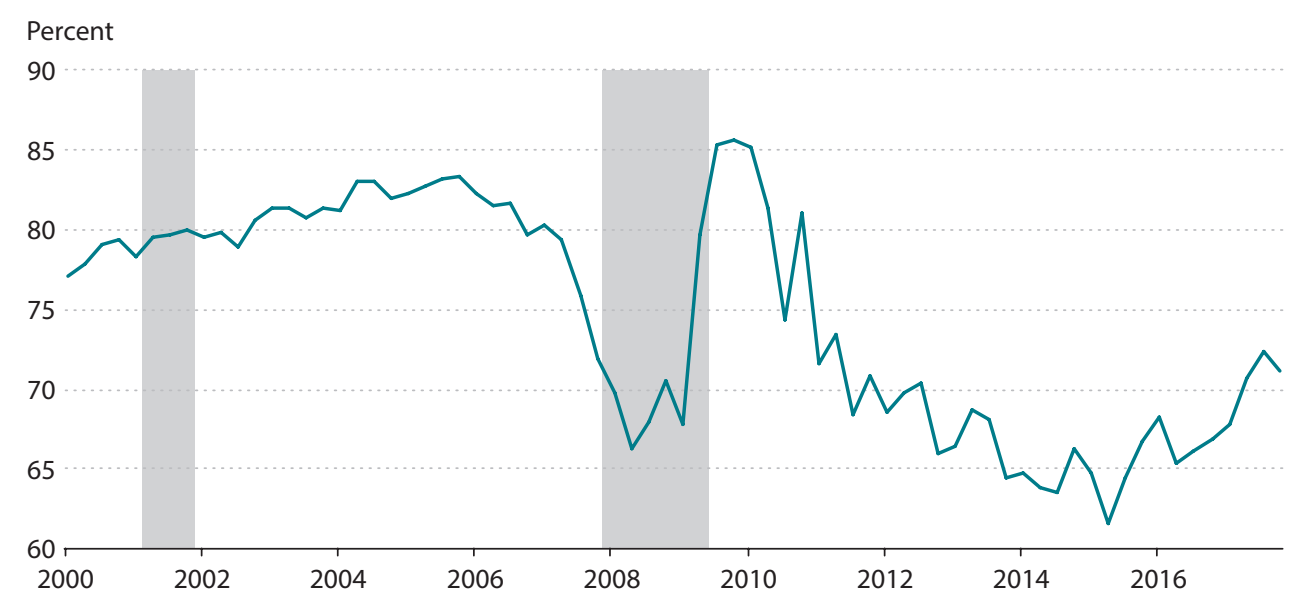

NOTE: SA, seasonally adjusted.

SOURCE: U.S. Census Bureau and Haver Analytics.

single-family units, which accounts for a large fraction of the 4.8 million-unit increase in total occupied singlefamily homes over that time frame. In addition, over the same time period, households with below-median income made up over 70 percent of all households that switched from homeownership to renting single-family housing. ${ }^{2}$

Increased rental demand has also likely reduced inventories of homes through its effect on new construction. The growth of rents relative to home prices after 2006 incentivized developers to concentrate more on multifamily construction. The fraction of all residential-unit starts in buildings with at least five units doubled from 16 percent in 2006 to 32 percent in 2016. And single-family construction projects declined sharply from 81 percent to 67 percent of all housing starts over the same 10-year period (Figure 2).

While both the increase in renter occupancy of singlefamily homes and the shift toward multifamily construction appear to have contributed to the current housing shortage, these trends seem to be easing as growth in rental demand has started to wane. ${ }^{3}$ Home prices have been growing faster than rents in recent years. If this continues, lessors may become inclined to sell, freeing up inventory. A rising home price-to-rent ratio may also encourage homebuilders to take on more single-family projects. The fraction of housing starts that are single-family units has already begun to rise, reaching 71 percent as of the fourth quarter of 2017 (the average from 2000 to 2006 was 81 percent). These trends are likely to be slow moving, meaning that any major inventory relief through these channels will take some time.

In Part 3 ("Price Gaps") of this series, we conclude our analysis by discussing recent trends across housing tiers and their potential effects on the housing supply.

\section{Notes}

1 We define young, middle-aged, and older households as those with heads of household younger than 45 years old, 45-64 years old, and 65 years old and over, respectively. Homeownership rates are calculated using data from the U.S. Census Bureau.

2 Calculated using data from the U.S. Census Bureau Current Population Survey.

${ }^{3}$ Based on data from the U.S. Census Bureau, the total number of renteroccupied housing units has remained effectively constant since the beginning of 2016 after consistently rising for over a decade. 